\title{
The Effect of Problem-Based Learning on Lateral Thinking Skills
}

\author{
Romy Faisal Mustofa
}

Faculty of Educational Sciences and Teachers' Training, Siliwangi University, Indonesia, syahla.aini@unsil.ac.id

\section{Yeni Ratna Hidayah}

Faculty of Educational Sciences and Teachers' Training, Siliwangi University, Indonesia,phytaloka@aol.com

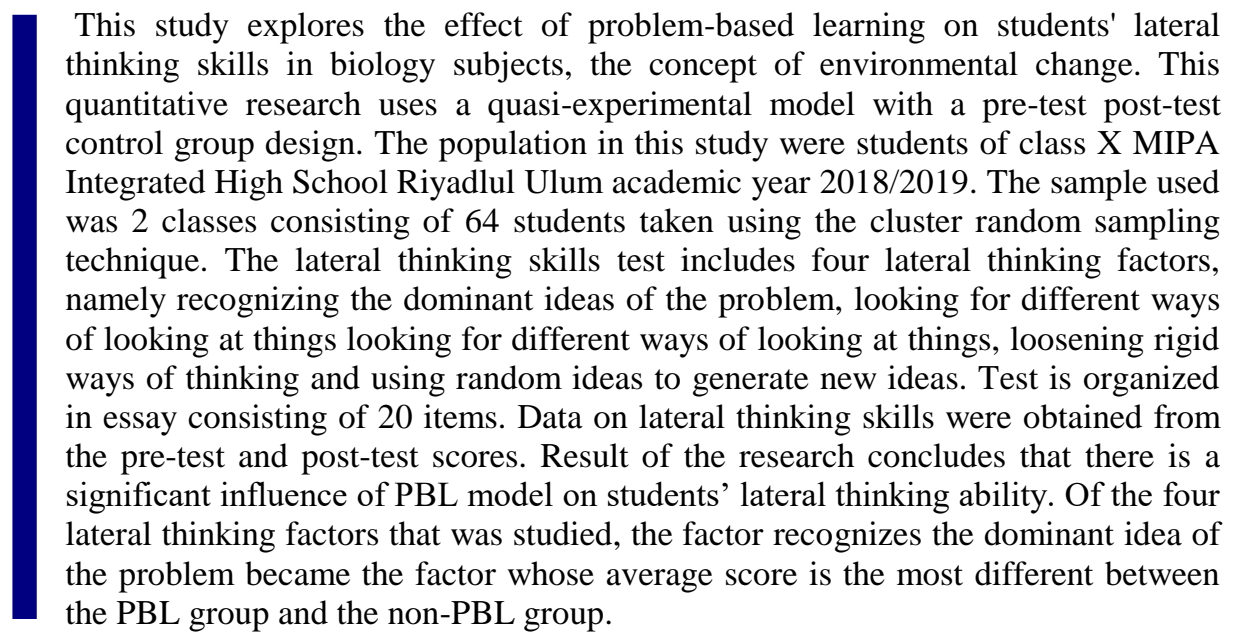

Keywords: problem-based learning, lateral thinking, learning process, collaborative, biology

\section{INTRODUCTION}

Learning that is needed in this time is learning that is not only repeats the ideas, but learning that is able to explore the new ideas from students. The exploration of this new idea can be done by students through processing the new information that is received and solving the problems they face during the learning process takes place. This is closely related to the methods and strategies applied by the teachers in the teaching and learning process.

Citation: Mustofa, R. F., \& Hidayah, Y. R. (2020). The Effect of Problem-Based Learning on Lateral Thinking Skills. International Journal of Instruction, 13(1), 463-474. https://doi.org/10.29333/iji.2020.13130a 
At present teaching and learning activities tend to be still oriented to the ability to test students' memory, so that they are unable to think in a pluralistic manner. Teachers should not only teach factual knowledge to students, but also skills for thinking and learning. Thinking skills must be an integral part of the school curriculum and should not be considered an aspect of isolated learning. Therefore, thinking skills must be integrated in subjects and at various levels.

Thinking according to Edwards, (2007) is "looking for meaning ... thinking is a mental process in which something is returned in the mind to make sense from experience", then according to Bono, (1970) the purpose of thinking is to gather information and use it to determine the best. Meanwhile, thinking skills according to Moseley et al., (2005) are mental processes that we use to do things such as: solving problems, making decisions, asking questions, planning, evaluating ideas, arranging information, and making objects. Thinking skills allow us to integrate every new experience into the scheme that we build. These skills are needed to give others more understanding of what they see and understand.

One of the thinking skills that students must have is lateral thinking skills. Lateral thinking is a kind of creative thinking (Fisher, 2005). Lateral thinking is a dimension of creative thinking. Those who have lateral thinking, at the same time, think creatively. Lateral thinking, is a way of handling information, provides a means to restructure thought patterns, to pave the way for new ideas to develop, which in turn may be needed in the future. Lateral thinking deals with the generation of ideas and approaches - order and sequence does not matter, whilst vertical thinking develops them in selective and hierarchical manners (Waks, 1997). Bono, (1994) defines lateral thinking as a series of processes about systematic and creative ways of thinking that produce innovative thinking repeatedly. Lateral thinking is one way of thinking that replaces conventional vertical thinking that only uses the logic of traditional thinking. This way of thinking, can demand students' thinking in solving problems critically and creatively. The condition of students actually wants learning that requires the use of their thinking to solve problems with diverse solutions. Edward de Bono originated the concepts of lateral thinking (literally sideways thinking) and parallel thinking to distinguish the many techniques for deliberative creative thinking that he has developed from what he considers to be normal perceptions regarding creativity and innovation (Burgh, 2016). Lateral thinking has positive relation with academic achievement, it fits More \& Jagadesh, (2017) with the conclusion that all the five dimensions of lateral thinking ability is positively correlated with academic achievement. Therefore, it can be concluded that efforts are made by teachers to develop lateral thinking ability of students along with teaching of academic subjects.

The teaching and learning process that has taken place so far especially at the high school level has not been as expected. Learning done in class should require students to think in a more creative direction in understanding a concept. Students are emphasized to be active in learning and the teacher places himself as a facilitator by preparing strategies, approaches and appropriate learning models. Often times students succeed in solving certain problems, but failure may occur if the concept is changed. Another 
description of the final outcome of the learning process that often occurs is the lack of ability of students to understand the concept contextually. This is possible because they have not trained their thinking skills during the learning process. The teacher as a facilitator can improve learning patterns such as by applying and varying learning models that are more student-centered.

Problem-based learning is one learning model that is student centered. This learning utilizes a constructivist approach, students strive to solve everyday problems in a collaborative environment. Through Problem-based learning, students can develop problem solving skills and critical thinking skills by generating information based on real life experiences and gaining knowledge about their own learning (al Wadani \& Khan, 2014). As White, (2001) notes, in the term "ill-structured" problem-based learning literature is used to describe open-ended problems that have many solutions and require students to choose various problem-solving methods before deciding on a particular solution (Shelton \& Smith, 1998). Unstructured problems can help students learn important concepts, ideas, and techniques (Galagher, 1997), because they can provoke them to discuss groups while providing their own experience in solving problems like researchers in the field. Students are given significant opportunities for creativity and flexibility in solving problem-based learning problems. This process will also foster students' assumption that the knowledge they get by thinking about the problems they face in learning will be useful in the future (White, 2001).

Various studies have been conducted which show the effect of problem-based learning in training and developing some thinking skills. Bashith \& Amin, (2017) in his study concluded that the problem-based learning model influences critical thinking skills and student learning outcomes in Malang 6 Public High School. Critical thinking skills and learning outcomes from the experimental group were higher than the control group. Another study conducted by Sihaloho, Sahyar, \& Ginting, (2017) shows that problembased learning has a significant influence on students' creative thinking and problemsolving abilities in physics learning. The value of student's creative thinking and problem-solving abilities of students taught with the problem-based learning model is better than conventional learning. This shows that the problem-based learning model has a better effect on student's creative thinking and problem-solving students' abilities. The results of the study of Kumar \& Refaei, (2017) concluded that problem-based learning in intermediate compositions can help students think more critically in their work as writers. Similarly, the results of Birgili's study (2015) concluded that with problembased learning students have the opportunity to discover new knowledge in solving problems they face, because problem-based learning exercises their creative and critical thinking skills.

Some research results that have been revealed show that problem-based learning is one of the learning models that can improve thinking skills. Therefore, the authors have an interest in conducting research on the effect of problem-based learning on one thinking skill, namely lateral thinking skills. This research is devoted to biology subjects in the concept of environmental change taught at the high school level. 


\section{METHOD}

\section{Research Design}

This research is a quantitative study using a quasi-experimental model with pre-test post-test control group design. The population in this study were students of class $\mathrm{X}$ MIPA Integrated High School Riyadlul Ulum 2018/2019 academic year spread in 7 classes. The sample used was 2 classes consisting of 64 students taken using the cluster random sampling technique. Class X MIPA-4 as an experimental class taught with problem-based learning and class X MIPA-3 as a control class taught by conventional models. Selection of cluster random sampling in determining the sample in this study because the population in this study does not consist of individuals, but consists of groups of individuals or classes.

Learning process in PBL class and non-PBL class was conducted in 4 meetings. In PBL class, students are taught to use PBL syntax namely (1) clarifying unknown terms, (2) problem definition, (3) brainstorming, (4) analyzing problems, (5) formulating learning objectives, (6) independent learning and (7) report the results of problem solving (Camp, van Het Kaar, van der Molen, \& Schmidt, 2014). Meanwhile, in PBL class and non PBL class, students conducted learning process as they used to do with using speech method, discussion and question and answer.

\section{Data Collection and Analysis}

The variables in this study consisted of independent variables and dependent variables. The independent variable is the problem-based learning model, while the dependent variable is lateral thinking skills. The instrument used in the research is a description test on the concept of environmental change that has met the criteria of validity and reliability. Before applying the instrument, validity test and reliability test are passed. Validity test level is between $0,485-0,722$ and its reliability 0,84 . The lateral thinking skills test includes four lateral thinking factors, namely recognizing the dominant ideas of the problem, looking for different ways of looking at things, loosening rigid ways of thinking and using random ideas to generate new ideas. Data on lateral thinking skills were obtained from the pre-test and post-test scores. The calculation results are derived from the reduction of the post-test and pre-test scores in the form of a gain score used to test the hypothesis. Data were analyzed using prerequisites and hypothesis testing. The normality test analyzed by Kolmogorov-Smirnov Test and homogeneity test were analyzed by Levene's Test of equality error variance. The hypothesis was analyzed using the t-test with a significance level of 0.05 with the help of SPSS Version 23 for Windows.

\section{FINDINGS}

The results of the study in the experimental class were taught with a problem-based learning model and in the control class taught by conventional models, presented in Table 1 . 
Table 1

Pre-Test, Post-Test and Lateral Skill Gain Score

\begin{tabular}{lllll}
\hline Group & Pre-test & Post-test & Gain & Categories \\
\hline Experiment & 17.94 & 31.19 & 0.46 & Medium \\
Control & 13.60 & 22.81 & 0.26 & Low \\
\hline
\end{tabular}

Table 1 shows that there are differences in the average pre-test score of the experimental class with the control class, as well as the average post-test and gain scores. The experimental class has a greater average score than the control class. While based on the gain, the control class is low. Next is the difference in average pre-test, post-test and gain for each lateral skill indicator in the experimental class and the control class. As explained earlier that in this study, lateral skills used 4 indicators, namely recognizing the dominant ideas of the problem, looking for different ways of looking at things, loosening rigid ways of thinking and using random ideas to generate new ideas.

Table 2

Differences in Pre-Test, Post-Test and Gain Average Scores in Experimental Classes and Control Classes on Each Lateral Skill Indicator

\begin{tabular}{|c|c|c|c|c|c|c|}
\hline \multirow{3}{*}{ Factors } & \multicolumn{6}{|c|}{ Average } \\
\hline & \multicolumn{3}{|c|}{ Experimental Class } & \multicolumn{3}{|c|}{ Control Class } \\
\hline & $\begin{array}{l}\text { Pre- } \\
\text { test }\end{array}$ & Post-test & Gain & $\begin{array}{l}\text { Pre- } \\
\text { test }\end{array}$ & Post-test & Gain \\
\hline $\begin{array}{l}\text { Recognize the dominant idea of the } \\
\text { problem }\end{array}$ & 2.29 & 3.59 & 0.76 & 1.79 & 2.84 & 0.47 \\
\hline $\begin{array}{l}\text { Look for different ways of looking } \\
\text { at things }\end{array}$ & 1.18 & 2.25 & 0.38 & 0.86 & 1.81 & 0.30 \\
\hline Loosen rigid thinking & 1.17 & 2.11 & 0.33 & 0.87 & 1.43 & 0.18 \\
\hline $\begin{array}{l}\text { Use random ideas to bring up new } \\
\text { ideas }\end{array}$ & 0.99 & 1.99 & 0.33 & 0.71 & 1.18 & 0.14 \\
\hline
\end{tabular}

Based on the table. 2, in all lateral skills factors, the class taught with the problem-based learning model is superior to the class taught with conventional models. Among the 4 careful factors, the most obvious difference in the average score of the factor recognizes the domain idea of the problem. In this factor the average pre-test score is 2.29 , the posttest is 3.59 and the gain is 0.76 (high categorized). While in the control class, the average pre-test score was 1.79 , the post-test was 2.84 and the gain was 0.47 (medium categorized). Meanwhile, the factors use random ideas to bring new ideas into factors whose differences are not too far away. Before the hypothesis is tested, the analysis prerequisites are tested, namely the test for normality and homogeneity. The results of the normality test data are presented in Table. 3. 
Table 3

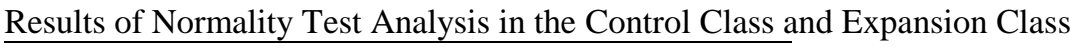

\begin{tabular}{llll}
\hline \multirow{2}{*}{ Group } & \multicolumn{3}{l}{ One-Sample Kolmogorov-Smirnov } \\
\cline { 2 - 4 } & Statistic & df & Significant \\
\hline Control Class & 0.077 & 32 & 0.200 \\
Experimental Class & 0.080 & 32 & 0.200 \\
\hline
\end{tabular}

Based on the analysis of the normality test in Table. 3 , it can be seen that the significance $=0.200$ greater than 0.05 (coefficient). This means that both groups of data (control class and experiment class) are from populations that are normally distributed. The test results of the homogeneity of the variance of the two groups of data are presented in Table. 4.

Table 4

Analysis of Variance Homogeneity Test Results

Test of Homogeneity of Variances

\begin{tabular}{llll}
\hline Levene Statistic & $\mathrm{df1}$ & $\mathrm{df} 2$ & Sig. \\
\hline 6.384 & 1 & 62 & 0.514
\end{tabular}

Based on the results of the homogeneity test, it shows that significance $=0.514$ greater than 0.05 (coefficient). So, it can be concluded that the data on lateral thinking skills are homogeneous. Lateral skill score data proved normal and homogeneous, then tested using the t-test. An independent t-sample test was used to determine the significance of specific differences between the two groups analyzed partially. The results of the t-test can be seen in Table 5 .

Table 5

Independent Sample T-Test Analysis Results

\begin{tabular}{lllll}
\hline & & \multicolumn{3}{l}{ t-test for Equality of Means } \\
\cline { 2 - 5 } $\begin{array}{l}\text { Gain Score of Lateral Thinking } \\
\text { Skill }\end{array}$ & \begin{tabular}{llll} 
Equal variances assumed \\
\cline { 2 - 5 }
\end{tabular} & $-7,074$ & 62 & 0,000 \\
\cline { 2 - 5 } & $\begin{array}{l}\text { Equal variances not } \\
\text { assumed }\end{array}$ & $-7,074$ & 51,596 & 0,000 \\
\hline
\end{tabular}

Table 5 shows that there are significant differences in lateral skills of students between the experimental group and the control group. This is evidenced by the results of the ttest analysis with a significant value ( 2 tailed) $=0,000$ less than 0.05 (coefficient). Based on the results of the test it can be concluded that the lateral thinking skills of students taught using problem-based learning are higher than conventional models.

\section{DISCUSSION}

In general, the results of this study indicate that there is an effect of problem-based learning on thinking skills. The results of this study are in line with the opinion of Arends, (2012) that the application of problem-based learning as a learning model has proven to be effective in improving high-level thinking skills. Strobel \& van Barneveld, (2009) provide the same review that problem-based learning is an ideal learning approach that can be used by teachers to assist students in determining solutions to "illstructured" problems. Furthermore, it was explained that, normally students are faced 
with problems that are "ill-structured" that will help students improve their thinking skills. This research is also in line with the conclusions of the study by Azaniar, (2017) that by using the problem-based learning model students can be more independent to get used to identifying, analyzing, and finding solutions to problems.

Problem-based learning in the learning process uses seven steps, namely (1) clarifying unknown terms, (2) problem definition, (3) brainstorming, (4) analyzing problems, (5) formulating learning objectives, (6) independent learning and (7) report the results of problem solving (Camp, van Het Kaar, van der Molen, \& Schmidt, 2014). The problembased learning model steps are enough to stimulate students' thinking critically on each topic of the problem that requires a solution that is in accordance with the material being taught. Problem-based learning facilitates the delivery of messages to students through the use of observation and identification techniques. This technique trains students to find solutions to broader and more comprehensive problems. The ability to observe and identify also helps students to understand the experience of involving themselves in the problem-solving process, this process can indirectly improve the ability to think laterally.

Jurkovic (2005) explained that brainstorming in PBL can train and develop students' lateral thinking skills. Brainstorming is a lateral thinking process that helps students decide on a problem by using a mindset that comes from various perspectives. In this process students are required to produce ideas spontaneously, quickly, broader and more varied. Furthermore, Bono (1970) explained that brainstorming is a formal rule used in practicing lateral thinking. Brainstorming is not a special technique but only a special rule to encourage the application of principles and techniques of lateral thinking in avoiding the vertical rigidity of thinking that has been used so far.

The four lateral thinking factors measured in this study include recognizing the dominant ideas of the problem, looking for different ways of looking at things, loosening rigid ways of thinking, using random ideas to generate new ideas (Bono, 1970). Factors recognizing the dominant idea of the problem in the experimental class showed a greater pretest score compared to the secondary class. The greater the score obtained is caused by learning with problem-based learning which exposes students to authentic problems. The findings of this study are in line with the opinion of Herrington, (2006) which states that authentic learning can develop students' thinking skills, because students will think more comprehensively in solving authentic problems. Yuliati, Fauziah, \& Hidayat, (2018) in her research stated that one of the learning models that can train thinking skills is a problem-based learning, because in this model students are faced with authentic problems. Problem-based learning choices have been widely adopted in various fields and educational contexts to enhance critical thinking and problem solving in authentic learning situations (Yew \& Goh, 2016). Setty, (2010) states that sharpening lateral thinking skills will open up new opportunities, because by lateral thinking, the solution found is really obtained from the situation in a totally new perspective. This is obtained from skills in recognizing the main idea of the problem at hand. 
Tan, (2004) explains that the problem presented in problem-based learning requires a lot of perspective in solving it. The use of cross-disciplinary knowledge is a key feature of problem-based learning. In any case, problem-based learning encourages solutions to problems by considering knowledge from various subjects and topics. The character of PBL described above is in line with the second factor in lateral thinking, which is looking for different ways of looking at things. This means that problem-based learning can train and develop lateral thinking skills in determining solutions to problems faced based on different perspectives. Major \& Palmer, (2001) found that students trained in problem-based learning tended to use a variety of versatile and meaningful approaches to learning, compared to non- problem-based learning students. Through PBL, students learn to connect newly received information with prior knowledge, previous experience, theories, new facts and ideas, other people's perspectives and real-world contexts (Tan, 2004). The results of the study and some of the opinions above are in accordance with the results of the research that has been conducted, that the lateral thinking skills of students in the experimental class are better than those in the control class.

Problem-based learning can loosen rigid thinking. This method is generated from the learning process that is student centered, requires active students, collaborative and cooperative activities during the learning process. This is explained by Wirkala \& Kuhn, (2011) that problem-based learning ensures the learning process takes place in an interesting atmosphere, because students can take part in learning activities without being limited in their ability to determine various ideas for the problems they face. Classes are more dynamic through learning discussions, questioning each other, producing creative ideas in finding solutions. The same thing was conveyed by Apriyani, Nurlaelah, \& Setiawati (2017), that problem-based learning encourages students to recognize ways of learning and collaborating in groups to solve contextual problems involving high-level thinking skills. The process of discussion that requires students to be active in arguing makes students not feel bored when they find a deadlock in finding ideas related to the problems presented.

The fourth factor of lateral thinking according to Bono, (1970) is to use random ideas to generate new ideas. Learning with the problem-based learning model does not only memorize facts, but students get the opportunity to present their ideas to a group, defend and revise them when needed. This shows that problem-based learning demands a diversity of ideas in finding solutions to the problems being discussed. The results of this study show that the diversity of ideas in problem-based learning classes is better than those in non- problem-based learning classes. Chen, (2011) revealed that PBL has the potential to increase students' responsibility in controlling their own learning. Students who are allowed to organize their own learning will be more involved in learning. Their involvement in problem-based learning involves framing problems; data collection; Different thoughts ideas or ideas vary in evaluating alternative solutions to problems and finding various solutions (Hmelo \& Ferrari, 1997). Through PBL, students learn a variety of new skills, new ways and new ideas to find alternative solutions to problem solving based on the knowledge they have before (Harland, 2002). Furthermore, Glaser (1991) revealed that students involved in problem-based learning would be accustomed to generating their problem-solving methods and conceptual 
knowledge. They express their new ideas to be applied in new situations and share responsibility in managing the problem situation in group work.

\section{CONCLUSION}

Problem-based learning is one of the student-centered learning models. Its use is intended to develop a variety of advanced cognitive abilities such as problem solving and communication skills and various student thinking skills including lateral thinking skills. This study aims to determine the effect of problem-based learning on students' lateral thinking abilities, especially in Biology subjects, the concept of environmental change. The results showed that there was a significant effect of the problem-based learning model on students' lateral thinking skills. Of the four factors of lateral thinking skills studied, the factor recognizing the dominant idea of the problem became the factor whose average score was the most different between the PBL group and the non-PBL group.

Lateral thinking skills become one of the important thinking skills for students. These skills train students to think creatively and systematically to produce innovative thinking. Students or someone who uses lateral thinking will create new ideas from ideas that were already known in solving problems. These skills are needed by students during their studies and when they graduate and work professionally. This research has a weakness that its sample used along with its research process; therefore, the next researcher is hoped to use sample more to add its significance of the research.

\section{REFERENCES}

al Wadani, F., \& Khan, A. (2014). Problem-based learning in ophthalmology: A brief review. Oman J. of Ophthalmology, 7(1), 1-2. doi: 10.4103/0974-620X.127908.

Apriyani, L., Nurlaelah, I., \& Setiawati, I. (2017). Penerapan model PBL untuk meningkatkan keterampilan berpikir kritis ditinjau dari kemampuan akademik siswa pada materi biologi. Quangga, 9(1), 41-54.

Arends, R. I. (2012). Learning to Teach. New York: The McGraw-Hill.

Azaniar, A. R. (2017). Model pembelajaran problem based learning (PBL) untuk meningkatkan kemampuan berfikir reflektif peserta didik kelas X SMA negeri 2 sigli. Universitas Islam Negeri Ar-Raniry Banda Aceh. Retrieved from https://repository.arraniry.ac.id/757/.

Bashith, A., \& Amin, S. (2017). The effect of problem based learning on EFL students' critical thinking skill and learning outcome. Al-Ta'lim, 24(2), 93-102. doi: 10.15548/jt.v24i2.271.

Birgili, B. (2015). Creative and critical thinking skills in problem-based learning environments. J. of Gif. Edu. and Cre., 2(2), 71-71. doi: 10.18200/JGEDC.2015214253.

Bono, E. De. (1994). Parallel thinking: From Socratic thinking to de Bono thinking. Melbourne, Victoria, Australia: Penguin Books. 
Bono, E. De. (1970). Lateral thinking: A textbook of creativity. penguin books (Vol. 3). London, England: Ward Lock Education. doi: 11.0002/bies.10094.

Burgh, G. (2016). Creative and lateral thinking: Edward de Bono. In D. C. Phillips (Ed.), Encyclopedia of educational theory and philosophy (pp. 187-188). Thousand Oakes, CA: Sage. doi:10.4135/9781483346229.n86.

Camp, G., van het Kaar, A., van der Molen, H., \& Schmidt, H. (2014). PBL : Step by step: A guide for students and tutors. Netherland: Institute of Psychology, Erasmus University Rotterdam.

Chen, J. Y. (2011). Problem-based learning: Developing resilience in nursing students. Kaohsiung J. of Medical Sciences, 27, 230-233. doi: 10.1016/j.kjms.2010.11.005.

Chin, C., \& Osborne, J. (2008). Studies in science education students ' questions : A potential resource for teaching and learning science. Studies in Science Education, 44(1), 1-39. doi: 10.1080/03057260701828101.

Edwards, S. L. (2007). Critical thinking: A two-phase framework. Nurse Education in Practice, 7(5), 303-314. doi: 10.1016/j.nepr.2006.09.004

Fisher, R. (2005). Teaching children to think. London: Nelson Thornes.

Galagher, S. A. (1997). Problem-based learning: Where did it come from, what does it do, and where is it going? Journal for the Education of the Gifted, 20(4), 332-362.

Glaser, R. (1991). The maturing of the relationship between the science of learning and cognition and educational practice. Learning and Instruction, 1(2), 129-144. doi: 10.1016/0959-4752(91)90023-2.

Harland, T. (2002). Zoology students' experiences of collaborative enquiry in problembased learning. Teaching in High. Edu, 7(1), 3-15. doi: 10.1080/13562510120100355.

Herrington, J. (2006). Authentic e-learning in higher education: Design principles for authentic learning environments and tasks. In T. Reeves \& S. Yamashita (Eds.), Proceedings of e-learn 2006-world conference on e-learning in corporate, government, healthcare, and higher education (pp. 3164-3173). Honolulu, Hawaii, USA: Association for the Advancement of Computing in Education (AACE).

Hmelo, C. E., \& Ferrari, M. (1997). The problem-based learning tutorial: Cultivating higher order thinking skills. Journal for the Education of the Gifted, 20(4), 401-422. doi: 10.1177/016235329702000405.

Iversen, A., Pedersen, A. S., Krogh, L., \& Jensen, A. A. (2015). Learning, leading, and letting go of control: Learner-led approaches in education. SAGE Open, 5(4), 1-11. doi: $10.1177 / 2158244015608423$. 
Jurkovic, V. (2005). Guide to problem-based learning: PBL within the context of ESP. Ljubljana: Slovene Association of LSP Teachers.

Kumar, R., \& Refaei, B. (2017). Problem-based learning pedagogy fosters students' critical thinking about writing Interdisciplinary Journal of Problem-Based Learning, 11(2), 5-10. doi: 10.7771/1541-5015.1670.

Major, C. H., \& Palmer, B. (2001). Assessing the effectiveness of problem-based learning in higher education: Lessons from the literature. Academic Exchange Quarterly, 5(1). $\quad$ Retrieved from http://www.rapidintellect.com/AEQweb/mop4spr01.htm.

Moseley, D., Baumfield, V., Elliott, J., Higgins, S., Miller, J., Newton, D. P., \& Gregson, M. (2005). Frameworks for thinking. frameworks for thinking: A handbook for teaching and learning. Cambridge: Cambridge University.

Setty, R. (2010). Lateral thinking mini workshop. Retrieved from http://rajeshsetty.com/2010/06/18/lateral-thinking-mini-workshop/

Shelton, J. B., \& Smith, R. F. (1998). Problem-based Learning in Analytical Science Undergraduate Teaching. Research in Science \& Technological Education, 16(1), 1929. doi: 10.1080/0263514980160102.

Sihaloho, R. R., Sahyar, S., \& Ginting, E. M. (2017). The effect of problem based learning (PBL) model toward student's creative thinking and problem solving ability in senior high school. Journal of Research \& Method in Education, 7(4), 11-18. doi: 10.9790/7388-0704011118.

Strobel, J., \& van Barneveld, A. (2009). When is PBL more effective? A meta-synthesis of meta-analyses comparing PBL to conventional classrooms. Interdisciplinary Journal of Problem-Based Learning, 3(1), 44-58. doi: 10.7771/1541-5015.1046.

Tan, S. O. (2004). Problem-based learning: The future frontiers. In. K. Tan, M. Lee, J. Mok, \& R. Ravindran (Eds.), Problem-based learning: New directions and approaches (pp.17-32). Singapore: Learning Academy, Temasek Centre.

Waks, S. (1997). Lateral thinking and technology education. Journal of Science Education and Technology, 6(4), 245-255. doi: 10.1023/A:1022534310151.

White, H. (2001). Problem-based learning. Stanford U. Newsl. on Teaching, 11(1), 1-6.

Wirkala, C., \& Kuhn, D. (2011). Problem-based learning in k-12 education: is it effective and how does it achieve its effects? American Educational Research Journal, 48(5), 1157-1186. doi: 10.3102/0002831211419491.

Yew, E. H. J., \& Goh, K. (2016). Problem-based learning: An overview of its process and impact on learning. Health Prof. Edu., 2(2), 75-79. doi: 10.1016/j.hpe.2016.01.004. 
Yuliati, L., Fauziah, R., \& Hidayat, A. (2018). Student's critical thinking skills in authentic problem based learning. Journal of Physics: Conference Series, 1013(1), 0-6. doi: 10.1088/1742-6596/1013/1/012025. 